\title{
Industrial Structure and Pollution in China, 2004-2017
}

\author{
Huashen $\mathrm{Cao}^{1,2^{*}}, \mathrm{Rijin} \mathrm{Li}^{1}$ \\ ${ }^{1}$ Lingnan Normal University, Department of Business, Zhanjiang 524048, Guangdong, China \\ ${ }^{2}$ Guangdong Coastal Economic Belt Development Research Center, Lingnan Normal University, Zhanjiang 524048, \\ Guangdong, China \\ *Corresponding author. Email: 77543039@qq.com
}

\begin{abstract}
Industrial development has significant impact on environment in China, thus causing social and economic concerns. In order to understand and examine the impact of industrial structure on pollution, this paper uses panel data of 259 cities in China over 2004-2017 and dynamic panel regression to investigate the relationship between industrial structure and pollution. The result shows that industrial structure optimization decreases pollution. The regression result indicates that $1 \%$ industrial structure change can reduce $0.46 \%, 0.25 \%$ and $0.08 \%$ pollution of sulfur dioxide, industrial dust and waste water.
\end{abstract}

Keywords: Industrial structure, Pollution, Dynamic panel regression

\section{INTRODUCTION}

As China continues to develop rapidly, it has become one the of largest economic entities in the world. In the meanwhile, its industrial structure has been changing. However, industrialization in China excessively depends on natural resource and land use, and still lacks technology innovation and human capital growth. Therefore, the industrialization in China generates much pressure to environment and brings pollution threat to people's living. In the past several decades, the government has been paying attention to the environment problems caused by industrialization and enacted many industrial policies to optimize industrial development, especially to adjust the industrial structure. On the other hand, since Kuznets curve has been proposed and widely discussed among researchers, the industrial structure has also been recognized as an important factor affecting the pollution. From the perspective of China development, this paper wants to examine the relationship between industrial structure and pollution.

Although China has great impact on world economy, its industry structure has several problems. China plays an important role of manufacture in world production chain, and the manufacture demands for much natural resources input. First, from the perspective of production, the structure of China's manufacturing industry is characterized by high energy consumption and high environmental cost. To be specific, many industries are highly dependent on natural resource and weak in independent development innovation, so they are very difficult to transform to sustainable production. Second, many industries have serious overcapacity and low added value of products. For a long time, Chinese medium and small size enterprises mostly adopt OEM production, to play roles at the middle and low end of the global value chain. Product design, key parts and equipment mainly depend on imports. Even for the products that occupy a certain share in the international market, Chinese manufacturers are more concentrated in process of assembly and manufacturing, and generally do not own the core technology. Third, industrialization causes large energy consumption and serious pollution. In 2013, the country consumed nearly 3.75 billion tons of standard coal in primary energy, accounting for $21.3 \%$ of the world's energy consumption and creating $11.6 \%$ of the world's GDP. Now industrial pollution emission in China, such as nitrogen oxides, sulfur dioxide, ammonia nitrogen and carbon dioxide, are ranked first in the world. Haze, water pollution and excessive heavy metals in soil have become social hazards. With the low efficiency, the consumption of natural resources brought by economic development is very intensive. Therefore, the industry production has brought more and more pressure to China's economic growth, society and environment.

Industrial structure adjustment is an important way to control the source of pollution. China's steel, cement, electronic industry and other high energy consumption 
and high emission industries account for a large proportion of pollution. Steel and cement production account for about $50 \%$ and $60 \%$ of the world's total production respectively, and coal production accounts for $50 \%$ of the world's total consumption. Such an industrial structure makes the pollutant emissions in many industries far exceed the capacity of the local environment. Therefore, the central government has set the goal and of de-capacity and optimize industrial structure adjustment with enactment of relative policy, and it also established environmental protection to prohibit and strictly control pollution, especially in the most concerned regions such as Beijing, Tianjin and Hebei.

\section{DATA AND METHODOLOGY}

\subsection{Data Description}

Restricted by data availability, this paper uses the panel data of 292 cities in China from 2004 to 2017 as research sample (Tibet, Hong Kong, Macau, and Taiwan are excluded because of missing data). The data of all variables are obtained from the China City Statistical Year Book (2004-2017).

\subsection{Econometric Model}

Previous studies have confirmed the effect of a pollution last year on pollution this year, which is referred as the lag effect. The pollution has lag effect for two reasons. First the pollution might stay in the atmosphere and be hard to decompose, so quite a part of pollution generated last year would also be recorded this year. Another reason is that the economic development in one city would be hard to switch its development mode, and similar development pattern would generate similar pollution volume. In order to control the lag effect of pollution, this paper adopt a dynamic panel regression model to estimate the examine the impact of industrial structure on pollution. This paper considers the regression model specification as shown in Equation (1).

$$
\begin{aligned}
& \ln _{-} \text {pollution }_{i, t}=a+b_{1} \ln _{-} \text {pollution }_{i, t-1} \\
& +b_{2} \text { indstr }+\sum_{k=1}^{n} b_{k} \text { control }_{k}+\varepsilon_{i, t}
\end{aligned}
$$

$\ln _{-}$pollution $_{i, t}$ and indstr ${ }_{i, t}$ represent the pollution and industrial structure in city $i$ at time $t$; controls $_{i, t}$ represent a series of control variables; $\varepsilon_{i, t}$ represents the error term; $b_{i}$ represents the estimated coefficients. Because this econometric model adds the lag variable of pollution to control the lag effect, and lag variable correlates with independent variable and error term, so this paper adopts difference GMM to estimate the coefficients.

In order to examine the effect of industrial structure on pollution, this paper selects industrial sulfur dioxide emission, industrial dust emission and industrial waste water discharge to measure pollution. These three variables have complete data so they can comprehensively reflect pollution level caused by industrialization. In the meanwhile, the paper takes reference of the method of many researchers such as $\mathrm{Wu}$ (2016) and $\mathrm{Li}$ (2013), that is, to use ratio of add-value of third industrial structure to add-value of second industrial structure to measure the industrial structure.

Otherwise, this paper selects population density, urbanization, urban green facility, economic development, urban transportation and electricity volume as control variables. The population density is calculated by total urban population divided by city area. Population density has significant impact on pollution. The agglomeration of people generates pollution in a faster speed, but it can alleviate pollution by innovation or adopting cleaner production (Zheng and $\mathrm{Lu}, 2018$ ). Also, urbanization is regarded as another factor affecting regional pollution. The fast and large scale urbanization induce population movement, production transformation and massive infrastructure construction. Pollution would be generated with these activities. The urbanization is calculated by number of urban citizens divided by the number of total population following most of studies. Economic development is measure by regional GDP, and it is regarded as a critical factor affecting pollution. In last, urban facility also affects the pollution, and this paper controls its affect by adding green facility, measured by urban green area, urban transportation volume and total electricity consumption volume. All variables other than industrial structure are taken logarithm in order to alleviate heteroscedasticity and non-linear effect. Some data is missing in original documents. The statistical summary is in Table 1.

Table 1. Statistical summary

\begin{tabular}{llllll}
\hline variable & $\mathrm{N}$ & mean & sd & min & $\max$ \\
\hline In_so2 & 4019 & 10.55 & 1.18 & 0.69 & 14.24 \\
In_dust & 4019 & 9.78 & 1.13 & 3.53 & 15.46 \\
In_wastewater & 4019 & 8.38 & 1.09 & 1.95 & 11.42 \\
indstr & 4012 & 0.84 & 0.44 & 0.09 & 9.48 \\
In_density & 4017 & 5.72 & 0.94 & -5.3 & 9.98 \\
In_urban & 3973 & -0.51 & 0.68 & -2.57 & 1.28 \\
In_green & 3992 & 6.44 & 1.11 & 0 & 10.31 \\
In_gdp & 4020 & 10.07 & 0.82 & 4.6 & 13.06 \\
In_trans & 3433 & 8.63 & 0.95 & 0.69 & 12.57
\end{tabular}




\section{RESULT AND DISCUSSION}

The regression result ais presented in table 2 . It shows that industrial structure optimization helps to mitigate the pollution, measured by sulfur dioxide (So2), dust and waste water. The coefficients are all significantly negative. $1 \%$ industrial structure change toward third industry decreases $0.46 \%, 0.25 \%$ and $0.08 \%$ pollution of each type. Also, the lag terms of all pollution variables are significantly positive, which are in accordance with the lag effect of pollution that most research confirmed. However, some variables are

contradictory to general intuition. The coefficients of urbanization and population density are both significantly negative, indicating increase of urbanization and population density help to decrease pollution. This might be explained by green urbanization policy proposed by central government in the past decades. The central government proposed new urbanization since 2014, and required green and balance development among regions. This proposal triggered a series of green policy which focus on industrial transformation and energy saving and emission reduction. In last urban facility might help to mitigate pollution, because coefficients of urban green facility are significantly positive, indicating the more green facility the less pollution.

Table 2. Dynamic panel regression

\begin{tabular}{|c|c|c|c|}
\hline Variables & $\begin{array}{l}(1) \\
\text { In_so2 }\end{array}$ & $\begin{array}{l}\text { (2) } \\
\text { In_dust }\end{array}$ & $\begin{array}{l}\text { (3) } \\
\text { In_wastewater }\end{array}$ \\
\hline L.In_so2 & $\begin{array}{l}0.230^{* * *} \\
(0.071)\end{array}$ & & \\
\hline L.In_dust & & $\begin{array}{l}0.397^{\star \star *} \\
(0.065)\end{array}$ & \\
\hline L.In_wastewater & & & $\begin{array}{l}0.779^{\star * *} \\
(0.050)\end{array}$ \\
\hline indstr & $\begin{array}{l}-0.465^{\star *} \\
(0.204)\end{array}$ & $\begin{array}{l}-0.256^{\star *} \\
(0.105)\end{array}$ & $\begin{array}{l}-0.089^{* * *} \\
(0.032)\end{array}$ \\
\hline In_density & $\begin{array}{l}-1.283 \mathrm{e}-01^{\star *} \\
(5.076 \mathrm{e}-02)\end{array}$ & $\begin{array}{l}-1.249 \mathrm{e}-01^{* \star *} \\
(3.876 \mathrm{e}-02)\end{array}$ & $\begin{array}{l}2.191 \mathrm{e}-02^{*} \\
(1.291 \mathrm{e}-02)\end{array}$ \\
\hline In_urban & $\begin{array}{l}-0.085^{\star *} \\
(0.037)\end{array}$ & $\begin{array}{l}-0.036 \\
(0.034)\end{array}$ & $\begin{array}{l}-0.065^{\star \star \star} \\
(0.017)\end{array}$ \\
\hline In_green & $\begin{array}{l}0.104^{\star *} \\
(0.053)\end{array}$ & $\begin{array}{l}0.119^{\star \star \star *} \\
(0.041)\end{array}$ & $\begin{array}{l}0.017 \\
(0.016)\end{array}$ \\
\hline In_gdp & $\begin{array}{l}-0.123 \\
(0.084)\end{array}$ & $\begin{array}{l}-0.044 \\
(0.056)\end{array}$ & $\begin{array}{l}-0.002 \\
(0.018)\end{array}$ \\
\hline In_trans & $\begin{array}{l}0.125^{\star * *} \\
(0.042)\end{array}$ & $\begin{array}{l}0.022 \\
(0.030)\end{array}$ & $\begin{array}{l}0.061^{* * *} \\
(0.017)\end{array}$ \\
\hline In_eletricity & $\begin{array}{l}0.285^{\star * *} \\
(0.040)\end{array}$ & $\begin{array}{l}0.157^{\star * *} \\
(0.031)\end{array}$ & $\begin{array}{l}0.060^{* * *} \\
(0.014)\end{array}$ \\
\hline Constant & $\begin{array}{l}5.268^{\star \star \star} \\
(0.672)\end{array}$ & $\begin{array}{l}4.388^{\star \star *} \\
(0.634)\end{array}$ & $\begin{array}{l}0.430^{\star \star} \\
(0.168)\end{array}$ \\
\hline $\begin{array}{l}\text { Observations } \\
\text { Number of cities }\end{array}$ & $\begin{array}{l}3056 \\
292\end{array}$ & $\begin{array}{l}3056 \\
292\end{array}$ & $\begin{array}{l}3056 \\
292\end{array}$ \\
\hline
\end{tabular}

Notes: Robust standard errors are reported in parentheses and $* * *, * *, *$ indicate significance at the $1 \%, 5 \%$, and $10 \%$ levels, respectively.

\section{CONCLUSION}

This paper adopts dynamic panel regression model and difference GMM to examine the relationship between industrial structure and pollution. The regression analysis indicates the industrial structure change help to decrease the pollution in three dimensions. Therefore, industrial structure optimization policy should be put forward continuously and keep up with sustainable development.

\section{AUTHORS' CONTRIBUTIONS}

Huashen Cao contributed to the conception of the study. Huashen Cao and Rijin Li performed the data analyses and wrote the manuscript.

\section{ACKNOWLEDGMENTS}

This research is supported by Guangdong Coastal Economic Belt Development Research Center, Lingnan Normal University(20203L08). 


\section{REFERENCES}

[1] Guo, Y.; Tong, L.; Mei, L. Evaluation and Influencing Factors of Industrial Pollution in Jilin Restricted Development Zone: A Spatial Econometric Analysis. Sustainability 2021, 13, 4194. https://doi.org/ 10.3390/su13084194

[2] Li J, Hou L, Wang L, Tang L. Decoupling Analysis between Economic Growth and Air Pollution in Key Regions of Air Pollution Control in China. Sustainability.2021;13(12):6600. https://doi.org/10.3390/su13126600

[3] Li H, Li Y, Lee M-K, Liu Z, Miao C. Spatiotemporal Analysis of Heavy Metal Water Pollution in Transitional China. Sustainability. 2015; 7(7):9067-9087. https://doi.org/10.3390/su7079067

[4] Auty, R. (1997). Pollution Patterns during the Industrial Transition. The Geographical Journal, 163(2), 206-215. doi:10.2307/3060184

[5] Grant, Don Sherman, Albert J. Bergesen, and Andrew W. Jones. "Organizational Size and Pollution: The Case of the U.S. Chemical Industry." American Sociological Review 67, no. 3 (2002): 389-407. Accessed June 26, 2021. doi: $10.2307 / 3088963$.

[6] Wu Zhenxin, Yan Hongju, Zhang Xuefeng. Interaction Research between Regional Industrial Structure and Air Pollution Based on SpSVAR Model. Commercial Research,2016(3):19-23. (In Chinese)

[7] Li Xiaosheng, Song Malin, An Qingxian. Heterogeneity of the Impact of China's Economic Growth on Environmental Pollution. Nankai Economic Research, 2013(5):96-114. (In Chinese)

[8] Grossman, Krueger. Economic Growth and the Environment. Quarterly Journal of Economics, 1995, 110(2): 356-372.

[9] Zhao, H., Cao, X. \& Ma, T. A spatial econometric empirical research on the impact of industrial agglomeration on haze pollution in China. Air Qual
Atmos
Health 13, 1305-1312
(2020).

https://doi.org/10.1007/s11869-020-00884-w 